\title{
Peertechz
}

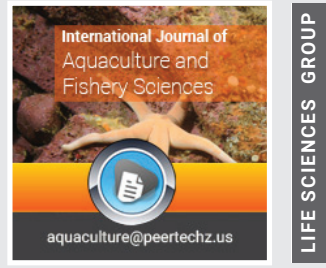

Research Article

\section{Age, growth and mortality of the European Seabass, (Dicentrarchus Labrax) in Bardawil lagoon, North Sinai,}

\section{Egypt}

\section{Menna 0 El-Desoki', Younis M Younis ${ }^{1}$, El-Dakar A Youssef ${ }^{1}$, Salem M Ahmed ${ }^{1}$, Kassem S Ahmed ${ }^{2}$ and Ahmed M Al- Beak $^{3 *}$}

${ }^{1}$ Faculty of Aquaculture and Marie fisheries, Arish University, Egypt

${ }^{2}$ Center Laboratory for Aquaculture Research (CLAR), Egypt

${ }^{3}$ Doctor of Fisheries Management, Marine Fisheries, Arish University, Egypt
Received: 16 September, 2021

Accepted: 04 October, 2021

Published: 05 October, 2021

*Corresponding authors: Ahmed M Al-Beak, Doctor of Fisheries Management, Marine Fisheries, Arish University, Egypt, Tel: 00201007264406 ;

E-mail: albeak2020@yahoo.com

ORCID: https://orcid.org/0000-0003-1338-5897

Keywords: Age; Growth; Mortality; European seabass; Bardawil lagoon

Copyright: (c) $2021 \mathrm{El}$-Desoki MO, et al. This is an open-access article distributed under the terms of the Creative Commons Attribution License, which permits unrestricted use, distribution, and reproduction in any medium, provided the original author and source are credited.

https://www.peertechzpublications.com

\section{Check for updates}

\section{Abstract}

Age, growth, and mortality of European Seabass (Dicentrarchus labrax) were studied from a small-scaled fishery of Bardawil lagoon, (North Sinai, Egypt). 181 specimens ( 16.6 to $35 \mathrm{~cm}$ total Length and 39.8 to $367.2 \mathrm{~g}$ total weight). The relationship between length and weight was $\mathrm{W}=0.0054 \mathrm{~L}^{3.1428}$. Age was determined by otoliths and age groups I to IV years were observed. Growths in length and weight at the end of each year were calculated. The growth parameters of von Bertalanffy equation were calculated as $\left(\mathrm{L}_{\infty}=48.69 \mathrm{~cm}, \mathrm{~K}=0.1677 \mathrm{yr}^{-1}\right.$ and $\left.\mathrm{t}_{0}=-0.447 \mathrm{yr}^{-1}\right)$. Growth performance index was calculated $(\varphi=2.60$ for length and 1.25 for weight). Mortality rates were $0.867 \mathrm{yr}^{-1}, 0.25 \mathrm{yr}^{1}$ and $0.617 \mathrm{yr}^{-1}$ for total, natural and fishing mortality, respectively. The currently exploitation rate $\mathrm{E}=0.712 \mathrm{yr}^{-1}$ indicating that, the population of this species is being heavily exploited.

\section{Introduction}

European Seabass, (Dicentrarchus labrax) belongs to family Moronidae. It is common fish in the Mediterranean Sea, the Black sea, along the Eastern Atlantic coasts and Eastern North Atlantic from Southern Morocco to the Norwegian littora. These species are demersal fish and it found in marine to slightly brackish environments $[1,2]$.

Abdel-Hakim, et al. 2010 [3] mentioned that, they are one of the important marine fishes in Bardawil Lagoon and have a great economic in Egypt. It the main demersal target of hand lines, long lines and trolling fisheries operating.

GAFRD 2018 [4] mentioned that, the total production of sea bass in Bardawil Lagoon increased to about 124 tons during the fishing season of 2016, as compared with 26-90 tons during 2003-2015 fishing seasons.
The some properties of Dicentrarchus labrax were investigated by researchers $[3,5-9]$.

Age determination is essential for studies of growth and population biology of Fisheries research. Also, the data on age structure can indicate the health of the population, mortality and survival rate [10-12].

The length-weight relationship is very crucial in estimating the standing stock biomass and discusses the development history of fish population from various regions [13]. It is an important fishery management tool and it is very beneficial for cultivators and fisheries managers to determine the growth of the species [14].

The current work amid to identify the biological aspects and exploitation rates of $D$. labrax in Bardawil lagoon recognizing age groups estimate growth rate and growth parameters, estimate mortality and utilization rates, and aims to develop 
an appropriate management plan to maintain this valuable fish resource. That could be useful for management of this important species.

\section{Material and methods}

\section{The study area}

Bardawil lagoon is a shallow (0.3 to $3 \mathrm{~m}$ depth) and hypersaline lagoon on the northern coast of Sinai. It lies between Lat $33^{\circ} 0^{\prime}$, Lon $31^{\circ} 9^{\prime}$ and covers an area of about $650 \mathrm{~km} 2$, with about $85 \mathrm{~km}$ length and a maximum width of $22 \mathrm{~km}$. It is separated from the sea by a sandbar that varies in width between $100 \mathrm{~m}$ and $1 \mathrm{~km}$. Three openings connect the lagoon with the sea; two artificial openings at the West side (Boughaz I and Boughaz II) and one natural opening at the East (El-Zaranik). Bardawil lagoon, particularly at Zaranik, has been identified as one of the most important wetlands for water-birds in the whole Mediterranean region (Figure 1).

\section{Sampling}

Monthly, random samples of European Seabass, (Dicentrarchus labrax) were collected from the mixed catch of the main landing site at the Bardawil lagoon. The sampling period lasted during the fishing season 2020-2021. The total length of 181 individuals of $D$. labrax from the tip of the snout to the end of the caudal fin was measured to nearest centimeter, total weight was measured to the nearest 0.1 gram. Otoliths were removed, of 181 individuals cleaned and stored dry in labeled vials, and examined calcified rings under the microscope to determine age groups.

\section{Data analysis}

For age determination, the Otoliths were cleaned by $8 \%$
$\mathrm{HCl}$, and then dried. The otoliths were cleared in a mixture of $50 \%$ ethyl alcohol and 50\% glycerin and they were examined using microscope. The opaque and transparent rings were counted from the nucleus to the margin along the longest axis of the otolith. One opaque zone together with one transparent zone was considered to be an annual increment. Each annual increment represents one year of the fish age [15]. The number of fish in each age group was calculated, and then the proportion of the different age groups of the fish in the catch was used to calculate the age composition of Dicentrarchus labrax. Lengths by age were back-calculated using [16] equation: $\mathrm{Ln}=(\mathrm{Sn} / \mathrm{S})$ L, where: $\mathrm{Ln}=$ is length of fish at age " $\mathrm{n}$ ", $\mathrm{Sn}=$ is magnified otolith radius to " $\mathrm{n}$ "annulus, $\mathrm{S}=$ is magnified total otolith radius, $\mathrm{L}=$ is fish length at capture.

The relation between the total length $(\mathrm{L})$ and total weight (W) was computed using the formula of [17] $\left(\mathrm{W}=\mathrm{a} \mathrm{L}^{\mathrm{b}}\right.$, where: $\mathrm{a}$ and $\mathrm{b}$ are constants whose values were estimated by the least square method).

Theoretical growth in length and weight was obtained by fitting the von Bertalanffy growth model, using the $[18,19]$ method [20] for theoretical growth in length can be written in the form: $\mathrm{L}_{\mathrm{t}}=\mathrm{L}_{\infty}\left[\left(1-\mathrm{e}-\mathrm{k}\left(\mathrm{t}-\mathrm{t}_{\mathrm{o}}\right)\right]\right.$

Where: $L_{t}=$ the length at age $t, L_{\infty}=$ the asymptotic length at $\mathrm{t}_{\infty}, \mathrm{K}=$ growth coefficient and $\mathrm{t}_{\mathrm{o}}=$ age at which the length is theoretically nil.

The calculation of constants of the Von Bertalanffy growth model by Ford - Walford method can be derived as follows: $\mathrm{K}$ $=-\operatorname{Ln} b L_{\infty}=a / 1-b$

Then, the constant to can be calculated by the following equation: $\mathrm{t}_{0}=\mathrm{t}+1 / \mathrm{k} \operatorname{Ln}\left(\mathrm{L}_{\infty}-\mathrm{Lt}\right) / \mathrm{L}_{\infty}$

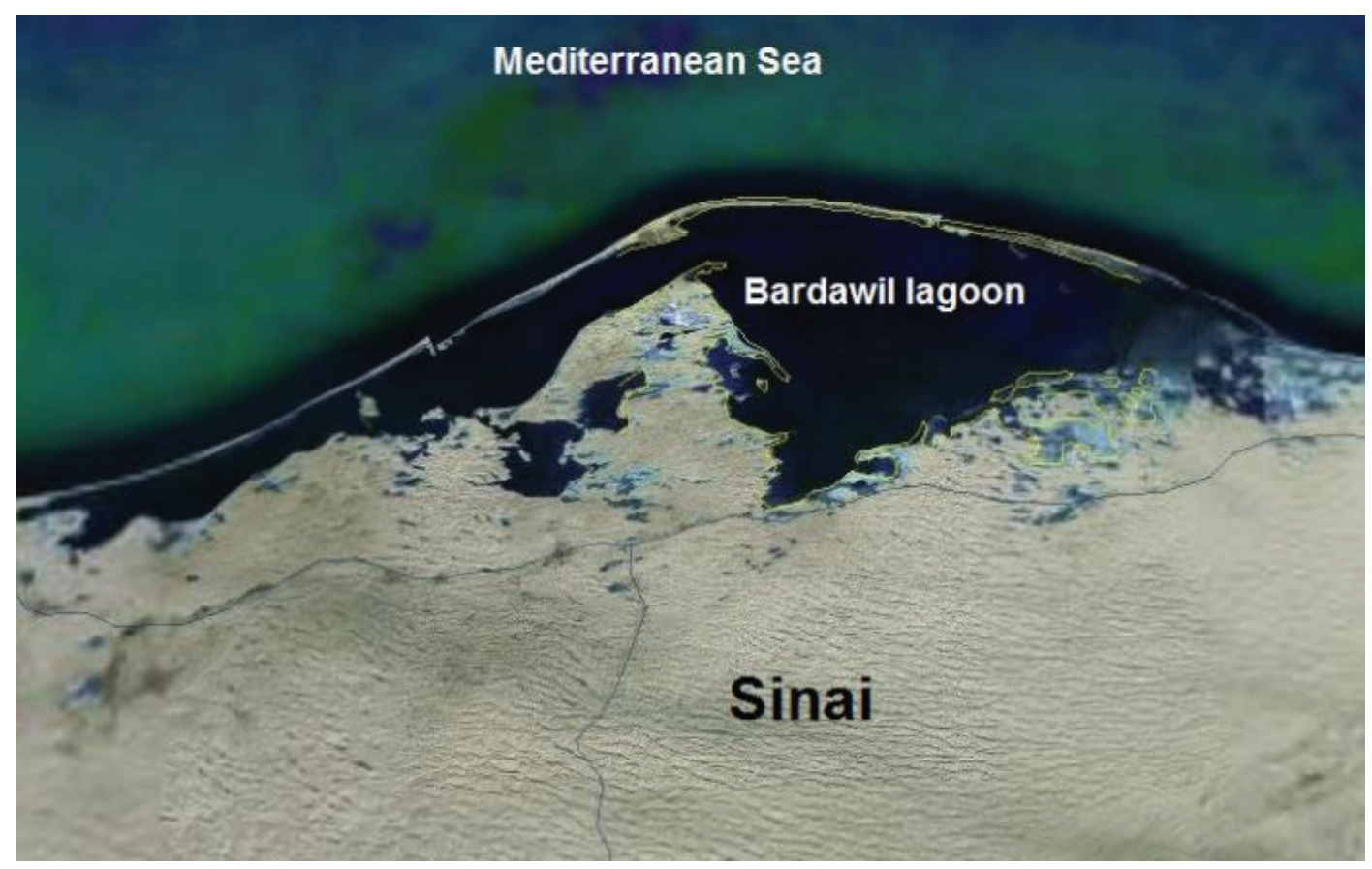

Figure 1: Map of Bardawil lagoon. 
The growth performance index $(\Phi)$ was estimated as: $\Phi=$ $\log \mathrm{K}+2 \log \mathrm{L}_{\infty}$ [21] where: $\mathrm{K}$ and $\mathrm{L}_{\infty}$ are parameters of von Bertalanffy).

Total mortality can be estimated using [22] method the following equation:

$\mathrm{S}=\sum \mathrm{N}-\mathrm{No} / \sum \mathrm{N}-\mathrm{Nx} \mathrm{Z}=-\mathrm{Ln} \mathrm{S}$

Where: $\mathrm{T}=\mathrm{N} 1+2 \mathrm{~N} 2+3 \mathrm{~N} 3+\ldots \ldots . . \mathrm{x} \mathrm{Nx}$; Notes $\Sigma \mathrm{N}=\mathrm{No}+$ $\mathrm{N} 1+\mathrm{N} 2+\ldots \ldots . . \mathrm{Nx}$; No is the number of fish in age - group I; $\mathrm{Nx}$ is the number of fish in age - group IV

Natural mortality coefficient ( $M)$ : $M=1.5 k$ [23]; Fishing mortality (F): It was calculated as $\mathrm{F}=\mathrm{Z}-\mathrm{M}$; Exploitation rate (E): the value of (E) was calculated after (Gulland, 1971) where $\mathrm{E}=\mathrm{F} / \mathrm{Z}$.

\section{Results and discussion}

Total of 181 European Seabass, Dicentrarchus labrax were measured as a total length $(\mathrm{cm})$. With lengths from 16.6 to $35 \mathrm{~cm}$ with weights ranging between 39.8 and 367.2g. The equation derived in respect of length-weight relationship is

As: Pooled: $\mathrm{W}=0.0054 \mathrm{~L}^{3.1428}\left(\mathrm{R}^{2}=0.9764\right)$.

The relationship equation showed a positive allometric in which $b=3.1428$.These result agree with that of [5] estimated the value of (b) as 3.142 in the England water [6] b value was 3.0551 and [24] resulted that, the value of (b) equals 3.2379. [9] found that, $b=3.0067$ in Bardawil lagoon Figure 2.

On the other hand, the result disagree with that of [25] found that, the value of (b) equals 2.8241 in the Mediterranean Sea, In Bardawil lagoon; [26] found that, the value of (b) was 2.8241 ; [27] mentioned that, the value of (b) at 2.7977 and 2.7316 during 2000 and 2001 respectively. And disagree with [28] estimated the b- value as 2.7977 and 2.69 during 2001 and 2002, respectively In Mediterranean Sea, Port Said, region [3] resulted that, the slope (b value) of the length weight relationship was 2.824 .

The (b) values in fish is species specific and varies with sex, age, seasons, physiological conditions, growth increment and nutritional status of fish, health, habitat, nutrition environmental conditions (such as temperature and salinity), area, degree of stomach fullness, differences in the length range of the caught specimen, maturity stage and techniques of sampling fishing gear $[10,17]$.

In the present work, the age determination of Dicentrarchus labrax was based on the otolith reading. 181 combined sexes using otolith. Age ranged from 1 to 4 years, ranged from 16.6 to $35 \mathrm{~cm}$ as a total length and from 39.8 to $367.2 \mathrm{~g}$ as a total weight. The mean fish length and the average otolith radii per each length group were given with the ratio of fish length in the total length / otolith radius relationship Figure 3.

Age composition of D. labrax in Bardawil lagoon during season 2020-2021 were constructed of combined sexes Tables 1 and Figure 4 show that the specimens of combined sexes belong to age group I to IV generally the different age groups cover wide length ranges.

These results disagree with both $[8,9]$ they found that, Age distribution of $D$. labrax samples from Bardawil Lagoon ranged from 0 to 6 years.

The age of D. labrax was determined by the annual rings of otolith of 181 specimens. Four age groups were observed. The average back-calculated lengths of European Seabass are given in Table 2 as were 9.89, 12.53, 14.23 and $15.58 \mathrm{~cm}$ and increment in length of age as were 9.89, 2.64, 1.70 and 1.35 for the 1st, 2nd, 3rd and 4th year of life, respectively. The highest annual increment occurred during the first year of life, while a noticeable decrease was observed in the second year, reaching to minimal value during the fourth year of life (Figures 3,5).

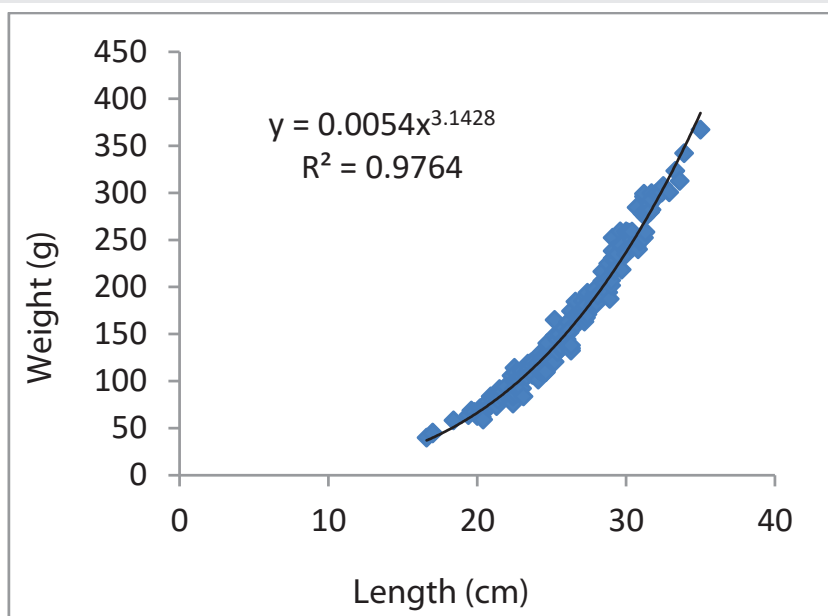

Figure 2: Length-weight relationship D. labrax $(\precsim \uparrow)$ collected from Bardawil lagoon during season 2020-2021.

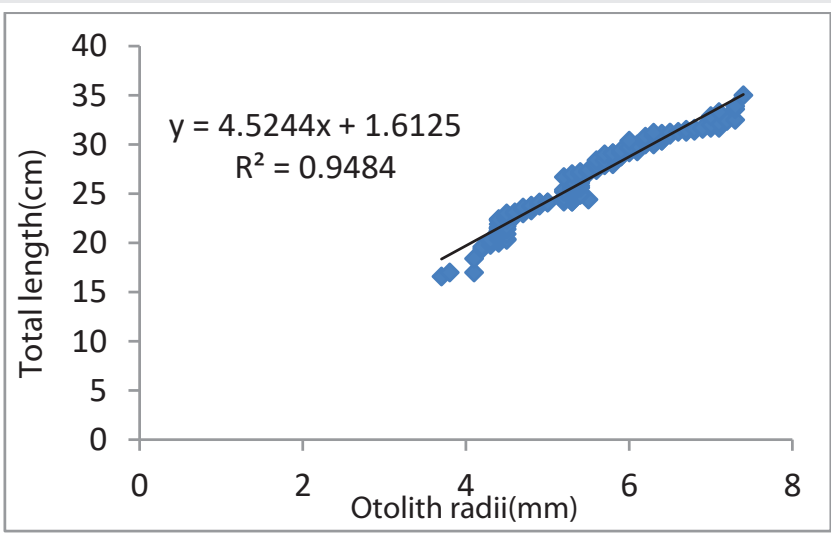

Figure 3: The relationship between total length $(T L)$ and otolith radius of combined sexes $(+\widehat{O})$ of $D$. labrax collected from Bardawil lagoon during season 2020-2021.

Table 1: Age composition of $D$. labrax collected from Bardawil lagoon during season, 2020-2021.

\begin{tabular}{|c|c|c|}
\hline \multirow{2}{*}{ Age group } & \multicolumn{2}{|c|}{ Sexes combined } \\
\cline { 2 - 3 } & number & $\%$ \\
\hline age1 & 6 & 3.3 \\
\hline age2 & 109 & 60.2 \\
\hline age3 & 48 & 26.5 \\
\hline age4 & 18 & 9.9 \\
\hline & 181 & \\
\hline
\end{tabular}

Citation: El-Desoki MO, Younis YM, A Youssef ED, Ahmed SM, Al-Beak AM, et al. (2021) Age, growth and mortality of the European Seabass, (Dicentrarchus Labrax) in Bardawil lagoon, North Sinai, Egypt. Int J Aquac Fish Sci 7(4): 042-046. DOI: https://dx.doi.org/10.17352/2455-8400.000072 
[9] mentioned that, the back-calculated lengths recorded in Bardawil lagoon for D. Labrax were 22.3, 28.3, 34.0, 38.4, 42.6 and $46.5 \mathrm{~cm}$ for age groups $1,2,3,4,5$ and 6 years, respectively.

In present study, The growth parameters of von Bertalanffy for European Seabass, (Dicentrarchus Labrax) were as follow; $\mathrm{L}_{\infty}=48.69 \mathrm{~cm}, \mathrm{~K}=0.1677$ year -1 and $\mathrm{t}_{0}=-0.447$ year $^{-1}[29]$ mentioned that the differences in growth parameters were due to age, sex, maturity and sampling period for the same species.

In Bardawil lagoon, (Egypt) by [9] growth parameters where found as $\mathrm{L}_{\infty}, \mathrm{K}$ and $\mathrm{t}_{0}$ was $75.31 \mathrm{~cm}, 0.1221 \mathrm{yr}^{-1}$ and -1.8703 $\mathrm{yr}^{-1}$ respectively. The growth parameters of von Bertalanffy for European Seabass, (Dicentrarchus Labrax) were as follow; $\mathrm{L}_{\infty}=$ $70.82 \mathrm{~cm}, \mathrm{~K}=0.35 \mathrm{yr}^{-1}$ and to $=-0.217 \mathrm{yr}^{-1}$ by $[7,8]$. resulted

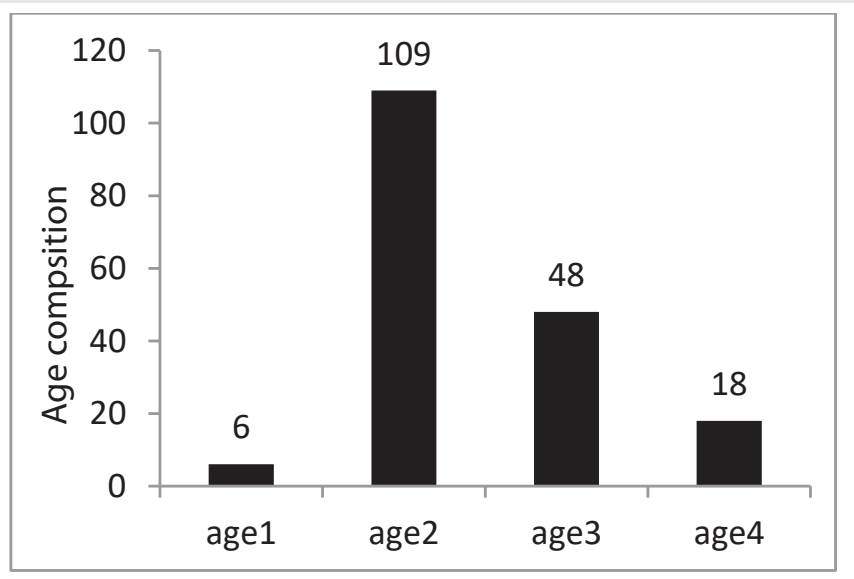

Figure 4: Age composition of combined sexes of $D$. labrax collected from Bardawil lagoon during season, 2020-2021.

Table 2: Back-calculation length at the end of different life years of, combined $D$. labrax collected from Bardawil lagoon during season 20-2021.

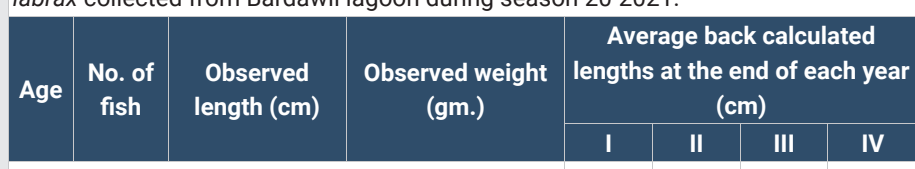

\begin{tabular}{|c|c|c|c|c|c|c|c|c|}
\hline \multicolumn{5}{|c|}{ combined sexes $(q \lambda)$} & \multirow[b]{2}{*}{15.48} & & & \\
\hline 1 & 6 & 18.0 & 53.4 & 83.8 & & & & \\
\hline II & 109 & 24.0 & 118.8 & 141 & 12.93 & 20.62 & & \\
\hline III & 48 & 29.6 & 232.6 & 193.8 & 12.99 & 19.63 & 24.84 & \\
\hline IV & 18 & 32.3 & 300.5 & 242.1 & 12.01 & 18.63 & 23.35 & 28.55 \\
\hline & & & & Increment & 15.48 & 5.14 & 4.22 & 3.71 \\
\hline
\end{tabular}

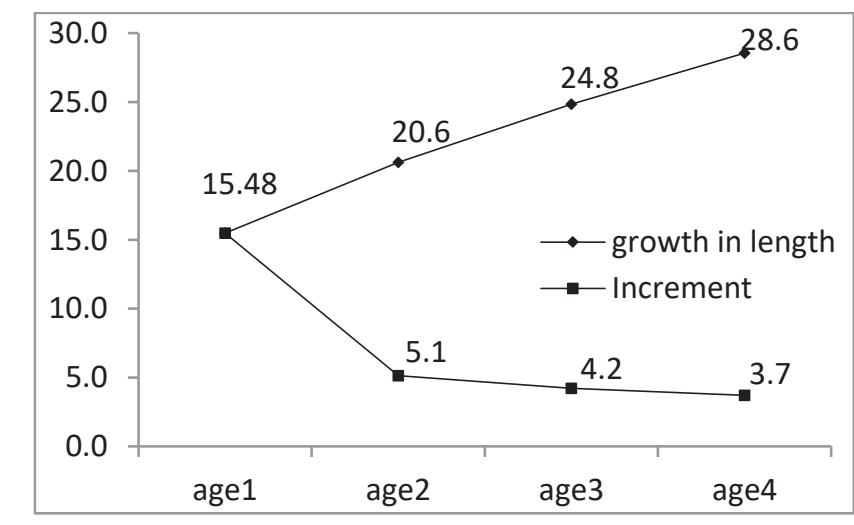

Figure 5: Growth and annual increment in length $(q \partial)$ of $D$. Labrax. that, growth parameters where found as $\mathrm{L}_{\infty} \mathrm{K}$ and $\mathrm{t}_{0}$ was 76.36 $\mathrm{cm}, 0.29 \mathrm{yr}^{-1}$ and $-0.19 \mathrm{yr}^{-1}$ respectively.

Growth performance index $(\Phi)$ of the same species reflects its adaptations to the environment factors. In current present, the growth performance index of D. labrax was 2.60 and 1.25 for length and weight, respectively. The growth performance index $(\Phi)$ defined as 2.84 and 1.4943 for length and weight, respectively [9]. Bardawil lagoon is better for the growth of $D$. labrax under study. Such differences may be attributed partially from the different techniques used, but more likely reflect slight environmental differences such as food availability and contents, height salinity in the lagoon and rise of temperature during 6 months at least [30].

The total mortality (Z) was calculated for D. labrax was 0.867 year $^{-1}$, the natural mortality coefficient (M) was 0.25 year ${ }^{-1}$, fishing mortality (F) was 0.617 year $^{-1}$. The exploitation level of this species was higher than the optimum one where the current $\mathrm{E}$ waso.712 indicating that, the population of this species is being heavily exploited.

[3] resulted that, the rates of total mortality $\mathrm{Z}$, natural mortality $M$, fishing mortality $\mathrm{F}$ and exploitation rate (E) were $1.54,0.36,1.18$ and $0.766 \mathrm{yr}^{-1}$ respectively for the same species in Bardawil lagoon. [9] found that, $\mathrm{Z}, \mathrm{M}$, and $\mathrm{F}$ values were $0.8786,0.3153$ and 0.5633 year $^{-1}$, respectively. $\mathrm{E}$ value was recorded as 0.64 year $^{-1}$.also [8], found that, total, natural and fishing mortality rates were $1.03 \mathrm{yr}^{-1}, 0.39 \mathrm{yr}^{-1}$ and $0.64 \mathrm{yr}^{-1}$, respectively. The current exploitation rate $(\mathrm{E}=0.6229)$.

According to [31,32] the $M$ value represents deaths from all occasion, except mans fishing involving predation, senility, epidemics, pollution, etc.

\section{References}

1. Fritsch M, Morizur $\mathrm{Y}$, Lambert E, Bonhomme F, Guinand B, et al. (2006) Assessment of sea bass (Dicentrarchus labrax, L.) stock de-limitation in the Bay of Biscay and the English Channel based on mark-recapture and genetic data. Fish Res 83: 123-132. Link: https://bit.ly/3DdZ81G

2. Mehanna SF (2006) Fisheries regulations based on yield per recruit analysis for the spotted Seabass Dicentrarchus punctatus (Moronidae) at Bardawil lagoon, Mediterranean coast of Sinai, Egypt. The $10^{\text {th }}$ conference about the Egyptian fisheries resources and aquaculture, Alex. Univ J Aquat Biol Fish 10 129-145. Link: https://bit.ly/3oGm0To

3. Abdel-Hakim NF, Mehanna SF, Eisa IA, Hussein MS, Al-Azab DA, et al. (2010) Length weight relationship, condition factor and stomach contents of the European sea bass, Dicentrarchus labrax at Bardawil Lagoon, North Sinai, Egypt. Proceeding of the 3rdGlobal Fisheries and Aquaculture Research Conference, Egypt 1-14. Link: https://bit.ly/3Bcw3mo

4. GAFRD (2018) The General Authority for Fishery Resources Development Fisheries Statistics Year Book for 2016. Ministry of Agriculture and Land Reclamation, Cairo, Egypt.

5. Aprahamian MW, Barr CD (1985) The growth, abundance and diet of o-group seabass (Dicentrarchus labrax), for the seven estuary. J Mar Biolo Assoc UK 169-180. Link: https://bit.ly/3Fm9SNE

6. Khalifa US (2005) Population characteristics and fisheries management of European seabass Dicentrarchus labrax L., in Bardawil lagoon, Egypt. Afr J Biol Sci 1: 69-78. 
7. Mehanna SF, El-Aiatt AA, Ameran M, Salem M (2010) Population dynamics and fisheries regulations for the European Seabass Dicentrarchus labrax (Moronidae) at Proc. of the $3^{\text {rd }}$ Global Fisheries \& Aquaculture Research Conference. Foreign Agricultural Relations (FAR), Egypt 199-209. Link: https://bit.ly/3ivQ5kl

8. Salem M (2011) Population dynamics and fisheries management of Gilthead sea bream, Sparus aurata (f. Sparidae) from Bardawil lagoon, North Sinai, Egypt. Egypt J Aquat Biol Fish 15: 1110 -1131.

9. Shalloof KA, El-Aiatt A, Mohammed SM (2019) Biological aspects of the european sea bass (dicentrarchus labraxl., 1758) from bardawil lagoon,north sinai, egypt. Egyptian Journal of Zoology (EJZ) 72: 11-21. Link: https://bit.ly/3uEt8Re

10. Nikolsky GV (1976) The Ecology of Fishes. Academic Press, London 3-352.

11. Begenal TB, Tesch FW (1978) Age and growth In: T. Bagena, editor, methods for assessment of fish production in fresh waters. IBp handbook No.3 (3rded) Black well Scientific publications, Oxford 101-136

12. Rounseefell GA, Everhart WH (1985) Fishery Science, Its Methods and Applications. International Books and Periodicals Supply Service, New Delhi 1- 444. Link: https://bit.ly/2WJU1a4

13. Petrakis O, Stergiou KI (1995) Weight-length relationships for 33 fish species in Greek waters. Fish Res 21: 465-469. Link: https://bit.ly/3D9eKUj

14. Nandikeswari R, Sambasivam M, Anandan V (2014) Length-weight relationship of Terapon jarbua (Forsskal, 1775) from Puducherry waters. Int J Biol Biomol Agric Food Biotechnol 8: 277-281. Link: https://bit.ly/3An59aN

15. El-Ganainy AA (1992) Biological Studies on lizard fishes, Saurida undosquamis (Pisces: Synodontidae) from the Gulf of Suez. M.Sc. thesis, Fac. Sci, Ain Shams Univ Cairo Egypt. Link: https://bit.ly/3mmV7kJ

16. Lee R (1920) A review of the methods of age and growth determination in fishes by means of scales. Fishery investigations, Series 2, Marine fisheries, Greet Britain Ministry of Agriculture, Fisheries and Food 4. Link: https://bit.ly/3Afzk3o

17. Le Cren ED (1951) The length-weight relationship and seasonal cycle in gonad weight and condition in the Perch (Perca fluviatilis). J Anim Ecol 20: 201-219. Link: https://bit.ly/3Bcx3ay

18. Ford $E$ (1933) An account of the herring investigation conducted at Plymouth J Marin Biol Ass UK 19: 305-384. Link: https://bit.ly/3layAs9
19. Walford LA (1946) A new graphic method of describing the growth of animals Mar Biol Bull 90: 141-147. Link: https://bit.ly/3DdprFj

20. Von Bertalanffy L (1949) Problems of organic growth. Nature 163: 156-158. Link: https://go.nature.com/3FkfYOU

21. Pauly D, Munro JL (1984) Once more on the comparison of growth in fish and invertebrates. ICLARM Fishbyte 2: 21. Link: https://bit.ly/3uGeqJC

22. Jackson CHN (1939) The analysis of animal population. J Anim Ecol 8: 238264. Link: https://bit.ly/3a6asAm

23. Jensen AL (1996) Beverton and Holt life history invariants result from optimal trade-off of reproduction and survival. Canadian Journal of Fisheries and Aquatic Sciences 53: 820-822. Link: https://bit.ly/3BcrHw1

24. Gaber MD (2007) Bio-Economic study on fishery management in Bardawil lagoon. Fac Env Agri Sci Suez Canal Univ El-Arish 167.

25. Rafail SZ (1971) Investigation on Sciaenidae and Moronidae catch and on the total catch by beach seine on U.A.R. Mediterranean Coast. Coun Gen Peches Mediterr Stud Rev 48: 1-26.

26. Hegazy MR, Sabry EA (2001) Stock assessment for the seabass (Dicentrarchus labrax L., 1758) - piscs: Moronidae in Bardawil lagoon, Egypt. J Egypt Ger Soc Zool 34: 41-55

27. Abd-Alla MSA (2004) Biological studies for the fishery regulation and management of the Bardawil lagoon. Ph. D. Thesis. Fac Env Agri Sci Suez Canal Univ El-Arish 184

28. Haggag HM (2005) Studies on fishing methods used in Port Said Fishery. Ph.D. Thesis. Fac Agri Suez Canal Univ 235

29. Mcllwain JL, Claereboudt MR, AL-Oufi HS, Zaki S, Goddard GS (2005) Spatial variation in age and growth of the Kingfish (Scomberomorus commerson) in the coastal waters of the Sultanate of Oman. Fish Res 73: 283-298. Link: https://bit.ly/3uFjzlb

30. El-Ganainy AA, Ahmed Al (2002) Growth, mortality and yield -per- recruit of the rabbitfish, Siganus rivulatus, from the eastern sid of the gulf of Suez, Sinai Coast, Red Sea. Egypt. J Aquat Biol Fish 6: 67-81.

31. Ricker WE (1975) Computation and Interpretation of Biological Statistics of Fish Populations. Bulletin of the Fisheries Research Board of Canada, Bulletin 191, Information Canada, Ottawa. Link: https://bit.ly/3uEwGTM

32. Tesch FW (1971) Age and growth in Fish Production in Fresh Waters. W. E. Ricker, Ed, Blackwell, Oxford, UK 98-130.

\section{Discover a bigger Impact and Visibility of your article publication with} Peertechz Publications
Highlights

* Signatory publisher of ORCID

* Signatory Publisher of DORA (San Francisco Declaration on Research Assessment)

* Articles archived in worlds' renowned service providers such as Portico, CNKI, AGRIS, TDNet, Base (Bielefeld University Library), CrossRef, Scilit, J-Gate etc.

* Journals indexed in ICMJE, SHERPA/ROMEO, Google Scholar etc.

* OAI-PMH (Open Archives Initiative Protocol for Metadata Harvesting)

* Dedicated Editorial Board for every journa

* Accurate and rapid peer-review process

* Increased citations of published articles through promotions

- Reduced timeline for article publication

Submit your articles and experience a new surge in publication services (https://www.peertechz.com/submission). 